\title{
Relationship between ecological stoichiometry and plant community diversity in the upper reaches of Tarim River, northwestern China
}

\author{
ZHAO Jingjing ${ }^{1,2}$, GONG Lu ${ }^{1,2^{*}}$, CHEN Xin ${ }^{1,2}$ \\ ${ }^{1}$ College of Resources and Environment Science, Xinjiang University, Urumqi 830046, China; \\ ${ }^{2}$ Key Laboratory of Oasis Ecology, Xinjiang University, Urumqi 830046, China
}

\begin{abstract}
Changes in ecological stoichiometry reflect nitrogen $(\mathrm{N})$, phosphorus $(\mathrm{P})$ and both $\mathrm{N}$ and $\mathrm{P}$ limitations in a plant community, which in turn affect plant diversity of the community. However, the relationship between plant community diversity and ecological stoichiometry has not yet been fully researched in arid and semi-arid regions. Ecological stoichiometry and plant community diversity indices of eighteen communities in the upper reaches of Tarim River, northwestern China, were analyzed by multivariate analysis of variance in 2016. The correlation between ecological stoichiometry and plant community diversity was assessed by redundancy analysis (RDA). Results indicated that the Margalef index was significantly correlated with carbon $(\mathrm{C})$ and $\mathrm{P}$ concentrations, the Simpson index and Shannon-Weaner index were significantly correlated with plant $\mathrm{C}$ concentration, and the Pielou index was significantly correlated with plant $\mathrm{C}$ and $\mathrm{N}$ concentrations. Moreover, C:N and C:P ratios had significant impacts on plant community diversity. Our results highlight the importance of ecological stoichiometry in driving plant community diversity in the upper reaches of Tarim River, northwestern China.
\end{abstract}

Keywords: Margalef index; Simpson index; Shannon-Weaner index; redundancy analysis; Tarim River

Citation: ZHAO Jingjing, GONG Lu, CHEN Xin. 2020. Relationship between ecological stoichiometry and plant community diversity in the upper reaches of Tarim River, China. Journal of Arid Land, 12(2): 227-238. https://doi.org/10.1007/s40333-019-0020-y

\section{Introduction}

Ecological stoichiometry is an important tool for exploring the dynamic balance of various nutrient elements (Sterner and Elser, 2002; Zechmeister-Boltenstern et al., 2015; Moorthi et al., 2016; Shang et al., 2018). At present, ecological stoichiometry has been applied to the molecules, cells, individuals, communities and ecosystems (Elser et al., 2007; Elser et al., 2010; Yan et al., 2016). It has also been used to estimate the nutrient limitation of plants and to reveal the nutrient utilization strategies of plants (Sterner and Elser, 2002). The lack of carbon (C), nitrogen (N) and phosphorus (P) nutrients can limit plant growth (Sperfeld et al., 2017; Zeng et al., 2017), thus decreasing plant community diversity (Conti and Díaz, 2013). Plant community diversity is important for maintaining the stability and process of an ecosystem (Tilman et al., 1996; Naeem and Li, 1997; Yachi and Loreau, 1999; Snyder et al., 2006; Haddad et al., 2011; Pelini et al., 2014; Vilela et al., 2016; Zhang et al., 2017; Bustos-Segura et al., 2017; Saitta et al., 2018). Therefore, using ecological stoichiometry method to study plant communities and their relationships can

*Corresponding author: GONG Lu (E-mail: gonglu721@163.com)

Received 2018-12-25; revised 2019-07-08; accepted 2019-07-15

C Xinjiang Institute of Ecology and Geography, Chinese Academy of Sciences, Science Press and Springer-Verlag GmbH Germany, part of Springer Nature 2020 
help to reveal the ecological strategies of plants in specific environments, and is of great significance to the material circulation and energy balance in a community.

Beginning in the 1980s, ecological stoichiometry has become an important method for plant ecology research (Frost et al., 2002; Allen and Gillooly, 2009; Yan et al., 2016; Yu et al., 2017a; Castellanos et al., 2018; Li et al., 2019). Researches mostly focus on the effect of ecological stoichiometry on plant community diversity (Kerkhoff et al., 2005; Liu et al., 2018; Huang et al., 2018) and examine the ecological stoichiometry of plant communities with different functional groups and changes in plant community diversity in grassland, forest and wetland ecosystems (Sardans et al., 2011; Yan et al., 2015; Tao et al., 2016; Soufbaf et al., 2017). However, little research was carried out on the desert ecosystem (Conti and Díaz, 2013). In addition, the study of ecological stoichiometry was always carried out at individual level not at the community level. (Halvorson et al., 2017; Zeng et al., 2017)

In northwestern China, because climate change and anthropogenic disturbances occur frequently (Chen, 2013; Zhang et al., 2018), plant communities of this region are extremely vulnerable and are expected to suffer sharp reductions in plant community density in the future (Liu et al., 2005). Plant communities in the upper reaches of Tarim River located in an especially fragile ecological zone in northwestern China (Gong et al., 2016), yet not much is known about these plant communities. Hence, exploring the impact of ecological stoichiometry on plant community diversity provides a scientific basis for guiding vegetation restoration of the desert ecosystem in the upper reaches of Tarim River. Here, we hypothesis that (1) characteristics of ecological stoichiometry will affect the distribution of plants, thereby affecting plant community diversity of the upper reaches of Tarim River; and (2) distance from the Tarim River will affect the characteristics of ecological stoichiometry and plant community diversity indices, but relationship between ecological stoichiometric and plant community diversity was not affected.

\section{Materials and methods}

\subsection{Study area}

The study area is located in the upper reaches of the Tarim River, northwestern China $\left(40^{\circ} 25^{\prime}-41^{\circ} 40^{\prime} \mathrm{N}, 80^{\circ} 10^{\prime}-84^{\circ} 36^{\prime} \mathrm{E}\right.$; Fig. 1). The annual mean temperature is $10.4^{\circ} \mathrm{C}$ and the mean annual precipitation and evapotranspiration are 50.4 and $1800.0 \mathrm{~mm}$, respectively (Gong et al., 2016). The dominant plant species in this desert ecosystem are Populus euphratica, Halostachys caspica, Tamarix chinensis, Phragmites communis, Lycium ruthenicum and Glycyrrhiza uralensis.

\subsection{Methods}

Data were collected at three sampling zones in the upper reaches of Tarim River in August 2016 (Fig. 1). The three zones were selected at the southern side of the river and named T1, T2 and T3, respectively. Within each sampling zone, six plant communities (i.e., sub-plots) were established to sample vegetation and the sub-plots were spaced at $1 \mathrm{~km}$ intervals so as to avoid problems of pseudoreplication. Thus, the total plant communities were eighteen and were coded (Table 1).

Different sub-plot sizes were used to sample trees, shrubs and herbs. Trees were sampled in a $20 \mathrm{~m} \times 20 \mathrm{~m}$ plot, while shrubs and herbs were sampled in $10 \mathrm{~m} \times 10 \mathrm{~m}$ and $1 \mathrm{~m} \times 1 \mathrm{~m}$ plots, respectively. Approximately $50 \mathrm{~g}$ of leaf material from these individual plant species were collected and placed in envelopes with desiccant. After removing litter and stones, the top soil $(0-15 \mathrm{~cm})$ of these plant species was taken to laboratory and soil characteristics were analyzed. The vegetation composition and soil characteristics of different communities are shown in Table 1.

\subsection{Leaf analyses}

Leaf samples were carefully cleaned and oven-dried at $60^{\circ} \mathrm{C}$ for $2 \mathrm{~h}$. Soil samples were air-dried after being sieved using a 2-mm mesh size, and visible roots and organic debris were removed by hand. All samples were then ground to a fine powder for element analysis (Soil Agrochemical Analysis (Bao, 2000)). Total C content was determined by using the potassium dichromate 


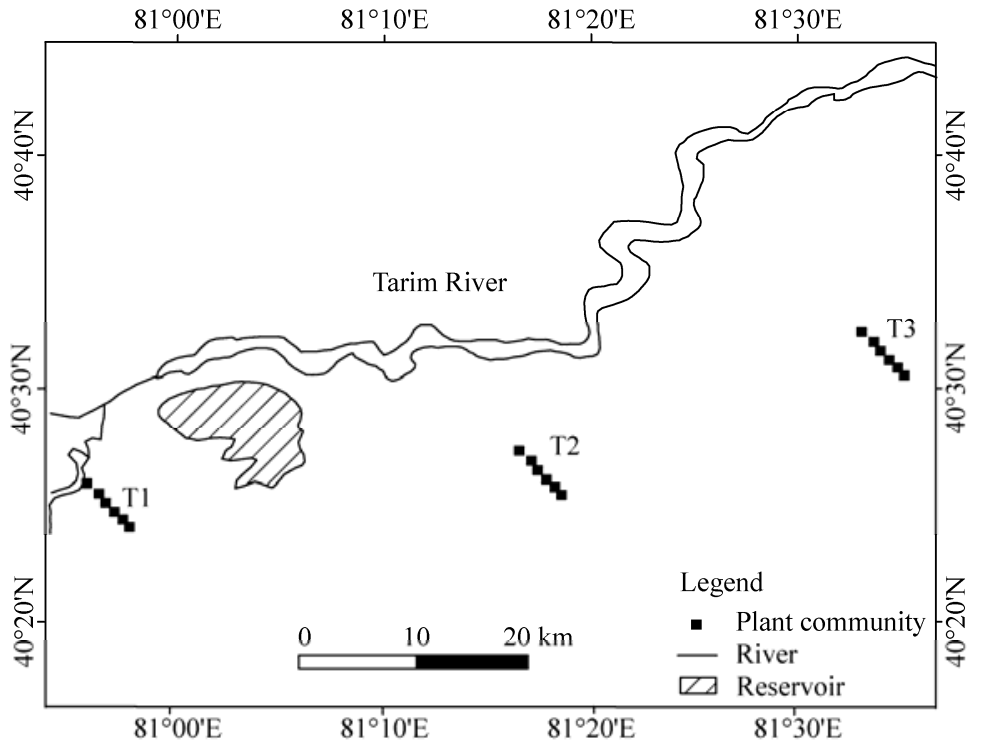

Fig. 1 Location of sampling zones in the upper reaches of Tarim River, northwestern China. T1, T2 and T3 are the sampling zones with six plant communities.

Table 1 Vegetation composition and soil characteristics of different communities

\begin{tabular}{|c|c|c|c|c|c|c|c|c|}
\hline $\begin{array}{l}\text { Community } \\
\text { code }\end{array}$ & Dominant species & $\begin{array}{c}\text { Total } \\
\text { number }\end{array}$ & Fre & $\mathrm{Cov}$ & $\begin{array}{l}\text { Soil C } \\
(\mathrm{g} / \mathrm{kg})\end{array}$ & $\begin{array}{l}\text { Soil N } \\
(\mathrm{g} / \mathrm{kg})\end{array}$ & $\begin{array}{l}\begin{array}{l}\text { Soil P } \\
(\mathrm{g} / \mathrm{kg})\end{array} \\
\end{array}$ & $\begin{array}{c}\text { Soil water } \\
\text { content }(\%)\end{array}$ \\
\hline T11 & $\begin{array}{l}\text { Populus euphratica, } \\
\text { Halostachys caspica }\end{array}$ & 168 & 1.39 & 0.69 & 6.58 & 0.59 & 0.63 & 12.57 \\
\hline $\mathrm{T} 12$ & P. euphratica, Tamarix chinensis & 524 & 1.77 & 0.31 & 4.75 & 0.52 & 0.57 & 13.11 \\
\hline T13 & $\begin{array}{l}\text { P. euphratica, Lycium ruthenicum, } \\
\text { Glycyrrhiza uralensis }\end{array}$ & 769 & 1.77 & 0.38 & 6.99 & 0.56 & 0.53 & 14.23 \\
\hline T14 & T. chinensis & 363 & 1.33 & 0.31 & 6.87 & 0.54 & 0.61 & 14.19 \\
\hline $\mathrm{T} 15$ & $\begin{array}{l}\text { P. euphratica, T. chinensis, } \\
\text { G. uralensis }\end{array}$ & 109 & 1.33 & 0.38 & 1.19 & 0.22 & 0.58 & 12.86 \\
\hline $\mathrm{T} 16$ & P. euphratica & 110 & 0.67 & 0.23 & 0.89 & 0.20 & 0.65 & 12.08 \\
\hline $\mathrm{T} 21$ & $\begin{array}{l}\text { T. chinensis, } \\
\text { Phragmites communis }\end{array}$ & 42 & 1.16 & 0.03 & 0.54 & 0.16 & 0.66 & 9.77 \\
\hline $\mathrm{T} 22$ & $\begin{array}{l}\text { T. chinensis, } \\
\text { Hexinia polydichotoma }\end{array}$ & 36 & 1.00 & 0.03 & 1.04 & 0.20 & 0.52 & 11.76 \\
\hline $\mathrm{T} 23$ & $\begin{array}{l}\text { Alhagi sparsifolia, } \\
\text { Karelinia caspia }\end{array}$ & 81 & 0.55 & 0.28 & 0.56 & 0.22 & 0.45 & 9.51 \\
\hline $\mathrm{T} 24$ & T. chinensis, A sparsifolia & 72 & 1.17 & 0.36 & 1.75 & 0.22 & 0.52 & 11.84 \\
\hline $\mathrm{T} 25$ & $\begin{array}{l}\text { P. euphratica, T. chinensis, } \\
\text { A. sparsifolia, K. caspia }\end{array}$ & 219 & 1.72 & 0.28 & 2.04 & 0.19 & 0.52 & 11.66 \\
\hline $\mathrm{T} 26$ & $\begin{array}{l}\text { A. sparsifolia, } \\
\text { P. euphratica }\end{array}$ & 43 & 0.56 & 0.04 & 1.82 & 0.22 & 0.50 & 9.70 \\
\hline $\mathrm{T} 31$ & $\begin{array}{l}\text { Halostachys caspica, } \\
\text { Kalidium foliatum }\end{array}$ & 80 & 1.11 & 0.63 & 4.66 & 0.38 & 0.50 & 6.24 \\
\hline $\mathrm{T} 32$ & H. caspica & 8 & 1.05 & 0.25 & 7.39 & 0.59 & 0.56 & 8.38 \\
\hline $\mathrm{T} 33$ & T. chinensis, H. polydichotoma & 45 & 1.00 & 0.25 & 7.33 & 0.68 & 0.49 & 9.19 \\
\hline $\mathrm{T} 34$ & $\begin{array}{l}\text { H. caspica, A. sparsifolia, } \\
\text { K. caspia }\end{array}$ & 336 & 1.61 & 0.28 & 4.28 & 0.62 & 0.51 & 5.05 \\
\hline T35 & $\begin{array}{l}\text { T. chinensis, A. sparsifolia, } \\
\text { K. caspia }\end{array}$ & 30 & 1.39 & 0.07 & 3.27 & 0.19 & 0.54 & 8.61 \\
\hline T36 & T. chinensis, $K$. caspia & 10 & 1.17 & 0.12 & 2.66 & 0.26 & 0.53 & 8.19 \\
\hline
\end{tabular}


external heating method (Bao, 2000), total $\mathrm{N}$ content was determined by using the Kjeldahl method (Bao, 2000) and total $\mathrm{P}$ content was determined by using the molybdenum-antimony colorimetric method (Bao, 2000). All leaf analyses were repeated three times.

\subsection{Alpha diversity indices}

Next, the alpha diversity indices were calculated by the following equations:

$$
\begin{gathered}
D=1-\sum P_{\mathrm{i}}^{2}, \\
H^{\prime}=-P_{i} \ln P_{i}, \\
M a=(S-1) / \ln N, \\
E=H^{\prime} / \ln S,
\end{gathered}
$$

where $D$ is the Simpson index; $H^{\prime}$ is the Shannon-Wiener index; $M a$ is the Margalef index; $E$ is the Pielou index; $P_{i}$ is the probability of occurrence of the $i^{\text {th }}$ species in a community; $S$ is the total number of species in a community; and $N$ is the total number of individuals in a community.

\subsection{Ecological stoichiometry}

Leaf $\mathrm{C}, \mathrm{N}$ and $\mathrm{P}$ concentrations were used to calculate the importance values of each community in trees, shrubs and herbs. According to these importance values, the stoichiometric eigenvalues for all of communities were weighted (Yan et al., 2008).

\subsection{Statistical analyses}

One-way analysis of variance (ANOVA) with a Duncan post hoc multiple comparisons test (Hsu, 1996.) was used to compare the differences in C:N:P ratios among different communities. All statistical tests were assessed at $P<0.05$ level. Linear regressions were then performed to describe the relationships between $\mathrm{C}, \mathrm{N}, \mathrm{P}, \mathrm{C}: \mathrm{N}$ ratio, $\mathrm{C}: \mathrm{P}$ ratio and $\mathrm{N}: \mathrm{P}$ ratio. These analyses were conducted in SPSS version 19.0 software (Chicago, IL, USA). Redundancy analysis (RDA) was used to explore the correlation between plant community diversity index and $\mathrm{C}, \mathrm{N}$ and $\mathrm{P}$ concentrations and their ratios. RDA was conducted in CANOCO 4.5 software (Wright, 2014). A Monte-Carlo test was performed to obtain the sequence of importance of variables.

\section{Results}

\subsection{Characteristics of ecological stoichiometry in different communities}

The highest $\mathrm{C}$ concentration occurred in T13 community and the lowest in T31 community. The highest $\mathrm{N}$ concentration occurred in T23 community and the lowest in T14 community. The highest $\mathrm{P}$ concentration occurred in T34 community and the lowest in T22 community. All of highest stoichiometric ratios (i.e., C:N, C:P and N:P ratios) occurred in $\mathrm{T} 1$ zone and the lowest in $\mathrm{T} 3$ zone (Table 2). Significant differences in $\mathrm{C}, \mathrm{N}$ and $\mathrm{P}$ concentrations and their ratios were observed within a zone and among different zones. In addition, $\mathrm{N}$ and $\mathrm{P}$ concentrations were not significantly different among T15, T25 and T35 communities (Table 2).

Figure 2 showed the correlations among different $\mathrm{C}, \mathrm{N}$ and $\mathrm{P}$ concentrations and their ratios. A strongly correlation was found between $\mathrm{C}$ and $\mathrm{N}$ concentrations, and between $\mathrm{C}$ and $\mathrm{P}$ concentrations (Fig. 2). A significant negative correlation was found between $\mathrm{C}: \mathrm{N}$ ratio and $\mathrm{N}$ concentration, and between $\mathrm{C}: \mathrm{N}$ ratio and $\mathrm{N}: \mathrm{P}$ ratio. A strong and positive correlation was found between $\mathrm{N}: \mathrm{P}$ ratio and $\mathrm{N}$ concentration and between $\mathrm{C}: \mathrm{P}$ ratio and $\mathrm{N}: \mathrm{P}$ ratio. However, an opposite pattern was found between $\mathrm{C}: \mathrm{P}$ ratio and $\mathrm{P}$ concentration.

\subsection{Characteristics of plant community diversity index in different communities}

There were significant differences in the Simpson's index between the communities in T1 and T3 zones. However, there was no significant difference in the other diversity indices between the communities in T1 and T3 zones (Fig. 3). For the Shannon-Wiener index, significant differences were observed between the communities in T1 and T2 zones, and in T1 and T3 zones, while no significant differences were observed between the communities in T2 and T3 zones (Fig. 3). For the Margalef index and the Pielou index, no significant differences were found among the 
Table 2 Characteristics of $\mathrm{C}, \mathrm{N}$ and $\mathrm{P}$ concentrations and their ratios in different communities

\begin{tabular}{|c|c|c|c|c|c|c|}
\hline $\begin{array}{c}\text { Community } \\
\text { code }\end{array}$ & $\begin{array}{c}\mathrm{C} \\
(\mathrm{mg} / \mathrm{g}) \\
\end{array}$ & $\begin{array}{c}\mathrm{N} \\
(\mathrm{mg} / \mathrm{g})\end{array}$ & $\begin{array}{c}\mathrm{P} \\
(\mathrm{mg} / \mathrm{g}) \\
\end{array}$ & $\mathrm{C}: \mathrm{N}$ ratio & $\mathrm{C}: \mathrm{P}$ ratio & $\mathrm{N}: \mathrm{P}$ ratio \\
\hline $\mathrm{T} 11$ & $428.33 \pm 1.04^{\mathrm{Bb}}$ & $16.74 \pm 0.06^{\mathrm{Ad}}$ & $1.32 \pm 0.07^{\mathrm{Aa}}$ & $26.05 \pm 1.94^{\mathrm{Bbc}}$ & $326.04 \pm 19.39^{\mathrm{Cc}}$ & $12.53 \pm 0.34^{\mathrm{Bd}}$ \\
\hline $\mathrm{T} 12$ & $447.70 \pm 11.76^{\mathrm{Aa}}$ & $18.58 \pm 0.96^{\mathrm{Aab}}$ & $1.10 \pm 0.04^{\mathrm{Ab}}$ & $24.12 \pm 0.62^{\mathrm{Bbc}}$ & $408.51 \pm 9.94^{\mathrm{Cb}}$ & $16.94 \pm 0.58^{\mathrm{Bc}}$ \\
\hline $\mathrm{T} 13$ & $453.39 \pm 3.43^{\mathrm{Aa}}$ & $19.59 \pm 0.92^{\mathrm{Aa}}$ & $1.09 \pm 0.02^{\mathrm{Ab}}$ & $23.18 \pm 1.28^{\mathrm{Bc}}$ & $414.34 \pm 5.02^{\mathrm{ABb}}$ & $17.92 \pm 1.16^{\mathrm{Ac}}$ \\
\hline $\mathrm{T} 14$ & $448.11 \pm 7.47^{\mathrm{Aa}}$ & $10.42 \pm 0.85^{\mathrm{Bd}}$ & $1.30 \pm 0.06^{\mathrm{Aa}}$ & $43.18 \pm 2.86^{\mathrm{Aa}}$ & $344.59 \pm 9.98^{\mathrm{Bbc}}$ & $7.99 \pm 0.33^{\mathrm{Be}}$ \\
\hline $\mathrm{T} 15$ & $434.91 \pm 2.33^{\mathrm{Ab}}$ & $17.47 \pm 1.01^{\mathrm{Abc}}$ & $0.67 \pm 0.09^{\mathrm{Bc}}$ & $24.95 \pm 1.30^{\mathrm{Abc}}$ & $653.89 \pm 89.28^{\mathrm{Aa}}$ & $26.14 \pm 2.35^{\mathrm{ABa}}$ \\
\hline $\mathrm{T} 16$ & $449.92 \pm 5.48^{\mathrm{Aa}}$ & $16.85 \pm 1.23^{\mathrm{Abc}}$ & $0.76 \pm 0.05^{\mathrm{Bc}}$ & $26.78 \pm 1.71^{\mathrm{Bb}}$ & $596.76 \pm 39.12^{\mathrm{Aa}}$ & $22.39 \pm 2.59^{\mathrm{Ab}}$ \\
\hline $\mathrm{T} 21$ & $451.39 \pm 1.00^{\mathrm{Aa}}$ & $11.40 \pm 1.17^{\mathrm{Bb}}$ & $0.95 \pm 0.01^{\mathrm{Bc}}$ & $39.87 \pm 4.01^{\mathrm{Aa}}$ & $474.62 \pm 4.67^{\mathrm{Bcd}}$ & $11.99 \pm 1.30^{\mathrm{Bb}}$ \\
\hline $\mathrm{T} 22$ & $420.51 \pm 1.05^{\mathrm{Bb}}$ & $14.64 \pm 1.04^{\mathrm{Bb}}$ & $0.59 \pm 0.01^{\mathrm{Ce}}$ & $28.82 \pm 1.20^{\mathrm{ABbc}}$ & $714.55 \pm 17.64^{\mathrm{Aa}}$ & $24.89 \pm 2.26^{\mathrm{Aa}}$ \\
\hline $\mathrm{T} 23$ & $441.61 \pm 10.29^{\mathrm{ABa}}$ & $20.67 \pm 2.26^{\mathrm{Aa}}$ & $0.92 \pm 0.10^{\mathrm{Bc}}$ & $21.51 \pm 2.02^{\mathrm{Bd}}$ & $486.68 \pm 59.06^{\mathrm{Ac}}$ & $22.93 \pm 4.94^{\mathrm{Aa}}$ \\
\hline $\mathrm{T} 24$ & $445.35 \pm 9.88^{\mathrm{Aa}}$ & $13.13 \pm 1.64^{\mathrm{Ab}}$ & $1.07 \pm 0.06^{\mathrm{Bb}}$ & $34.24 \pm 4.07^{\mathrm{Bab}}$ & $418.7 \pm 32.72^{\mathrm{Ad}}$ & $12.34 \pm 1.65^{\mathrm{Ab}}$ \\
\hline $\mathrm{T} 25$ & $435.52 \pm 13.37^{\text {Aab }}$ & $18.76 \pm 2.57^{\mathrm{Aa}}$ & $0.69 \pm 0.02^{\mathrm{ABd}}$ & $23.56 \pm 3.81^{\mathrm{Acd}}$ & $629.96 \pm 34.95^{\mathrm{ABb}}$ & $27.07 \pm 3.11^{\mathrm{Aa}}$ \\
\hline $\mathrm{T} 26$ & $400.73 \pm 10.03^{\mathrm{Bc}}$ & $14.51 \pm 1.92^{\mathrm{ABb}}$ & $1.36 \pm 0.03^{\mathrm{Aa}}$ & $27.97 \pm 4.21^{\mathrm{Bbcd}}$ & $295.74 \pm 13.95^{\mathrm{Be}}$ & $10.70 \pm 1.33^{\mathrm{Bb}}$ \\
\hline $\mathrm{T} 31$ & $391.05 \pm 1.46^{\mathrm{Cc}}$ & $11.35 \pm 0.84^{\mathrm{Bc}}$ & $0.69 \pm 0.01^{\mathrm{Cc}}$ & $34.58 \pm 2.66^{\mathrm{Aa}}$ & $562.76 \pm 4.96^{\mathrm{Aa}}$ & $16.07 \pm 0.73^{\mathrm{Abc}}$ \\
\hline $\mathrm{T} 32$ & $405.37 \pm 5.95^{\mathrm{Bbc}}$ & $11.62 \pm 2.00^{\mathrm{Cbc}}$ & $0.71 \pm 0.02^{\mathrm{Bc}}$ & $35.67 \pm 6.84^{\mathrm{Aa}}$ & $567.44 \pm 16.64^{\mathrm{Ba}}$ & $16.05 \pm 0.72^{\mathrm{Bbc}}$ \\
\hline $\mathrm{T} 33$ & $432.19 \pm 11.33^{\mathrm{Ba}}$ & $14.07 \pm 1.59^{\mathrm{Bbc}}$ & $1.26 \pm 0.11^{\mathrm{Ab}}$ & $35.22 \pm 4.88^{\mathrm{Aab}}$ & $345.24 \pm 24.51^{\mathrm{Bc}}$ & $11.31 \pm 2.23^{\mathrm{Bc}}$ \\
\hline T34 & $433.15 \pm 22.08^{\mathrm{Aa}}$ & $14.58 \pm 0.02^{\mathrm{Ab}}$ & $1.46 \pm 0.10^{\mathrm{Aa}}$ & $29.72 \pm 1.54^{\mathrm{Bab}}$ & $297.79 \pm 6.26^{\mathrm{Cc}}$ & $10.05 \pm 0.72^{\mathrm{Bc}}$ \\
\hline $\mathrm{T} 35$ & $419.32 \pm 11.91^{\mathrm{Aab}}$ & $17.93 \pm 2.81^{\mathrm{Aa}}$ & $0.83 \pm 0.08^{\mathrm{Ac}}$ & $23.80 \pm 3.93^{\mathrm{Ab}}$ & $507.29 \pm 52.38^{\mathrm{Bb}}$ & $21.50 \pm 2.34^{\mathrm{Ba}}$ \\
\hline T36 & $443.39 \pm 18.88^{\mathrm{Aa}}$ & $12.84 \pm 0.45^{\mathrm{Bbc}}$ & $1.37 \pm 0.02^{\mathrm{Aab}}$ & $34.53 \pm 0.52^{\mathrm{Aa}}$ & $323.74 \pm 19.57^{\mathrm{Bc}}$ & $9.37 \pm 0.49^{\mathrm{Bc}}$ \\
\hline
\end{tabular}

Note: Different uppercase letters within a column are significant differences among $\mathrm{C}, \mathrm{N}$ and $\mathrm{P}$ concentrations and their ratios at different zones (T1, T2 and T3) in the same community at $P<0.05$ level. Different lowercase letters within a column indicate significant differences among $\mathrm{C}, \mathrm{N}$ and $\mathrm{P}$ concentrations and their ratios at different communities in the same zone at $P<0.05$ level.
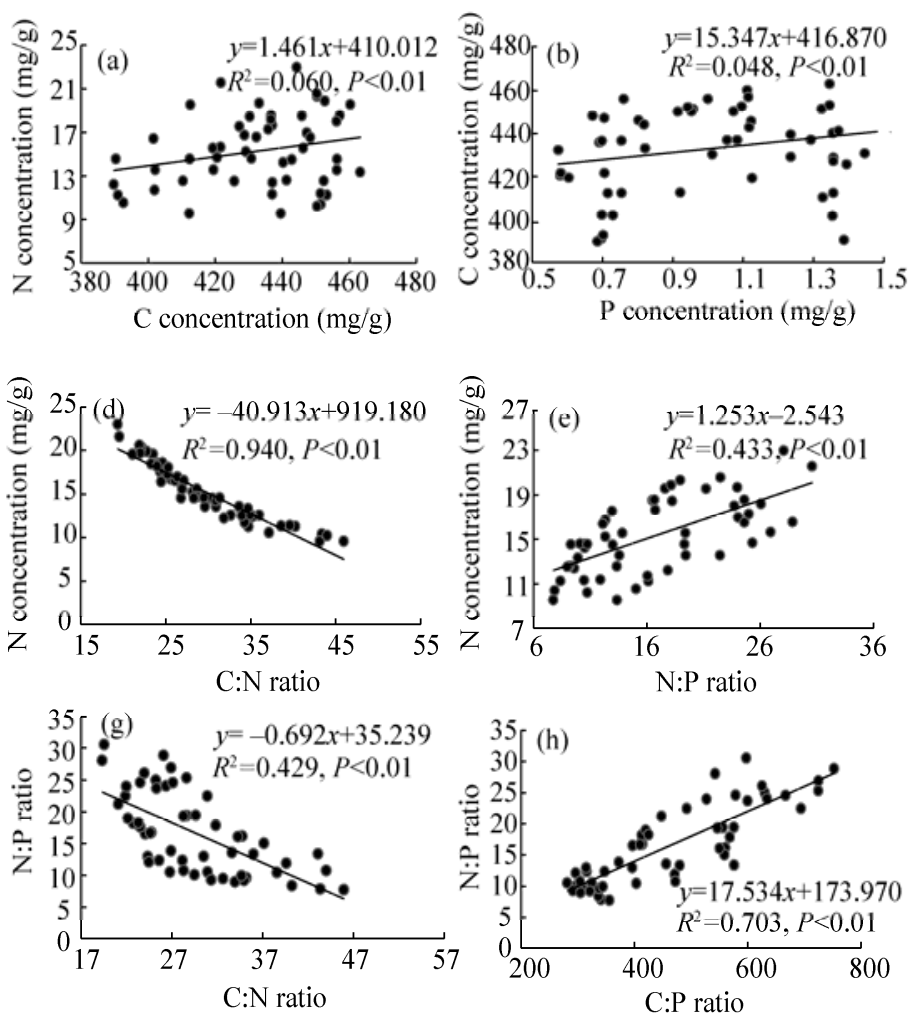
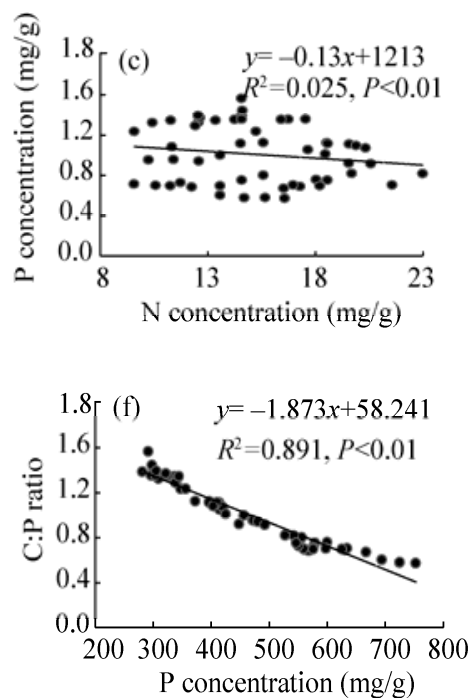

Fig. 2 Correlations among $\mathrm{C}, \mathrm{N}$ and $\mathrm{P}$ concentrations and their ratios 

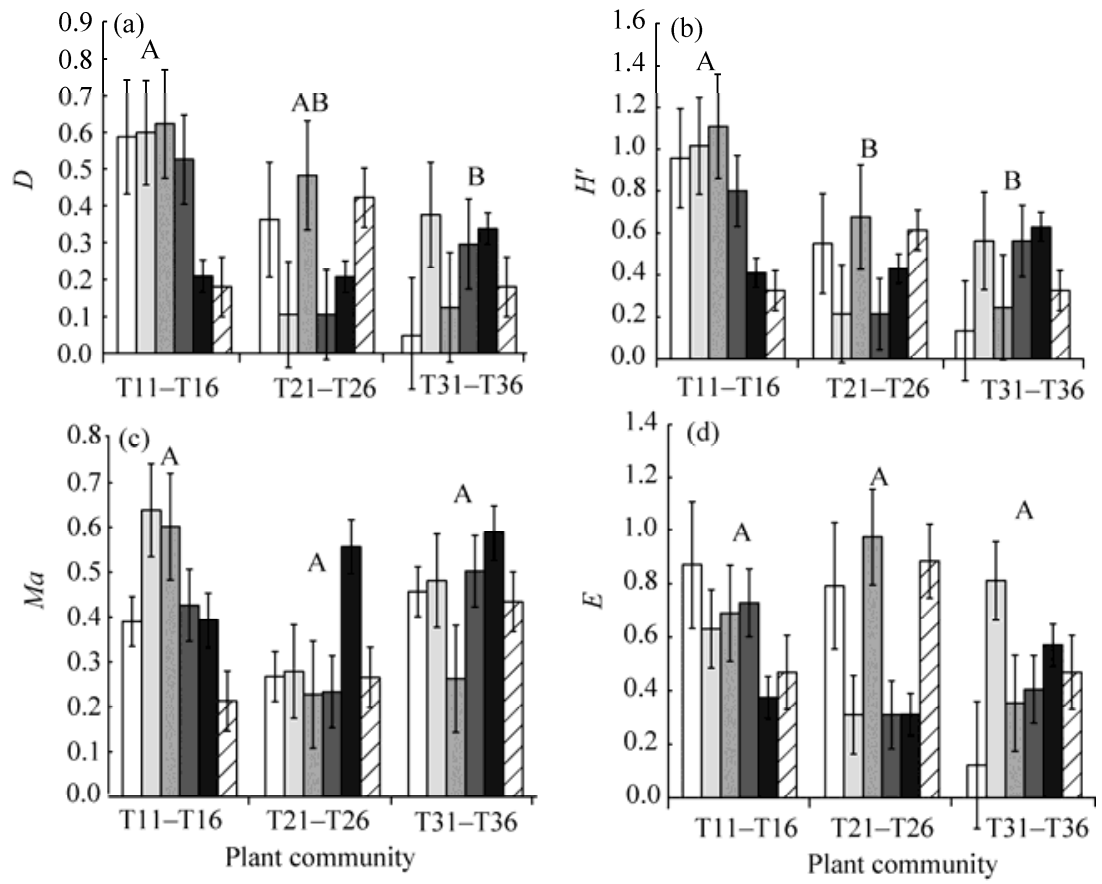

Fig. 3 Simpson's index $\left(D ;\right.$ a), Shannon-Wiener index $\left(H^{\prime} ; \mathrm{b}\right)$, Margalef index $(M a ; \mathrm{c})$ and Pielou index $(E ; \mathrm{d})$ in different plant communities. Different uppercase letters indicate significant differences among plant community diversity indices in T1, T2 and T3 zones at $P<0.05$ level. Bars indicate standard errors. T11-T16, T21-T26 and T31-T36 mean the six plant communities in T1, T2 and T3 zones, respectively.

communities in T1, T2 and T3 zones. Overall, for all plant community diversity indices, higher values occurred in the plant communities in T1 zone than in T2 and T3 zones.

\subsection{Correlations between ecological stoichiometry and plant community diversity index}

RDA was used to examine the correlation between plant community diversity and ecological stoichiometry (Fig. 4). The first axis explained 64\% of the variation, while the second axis only

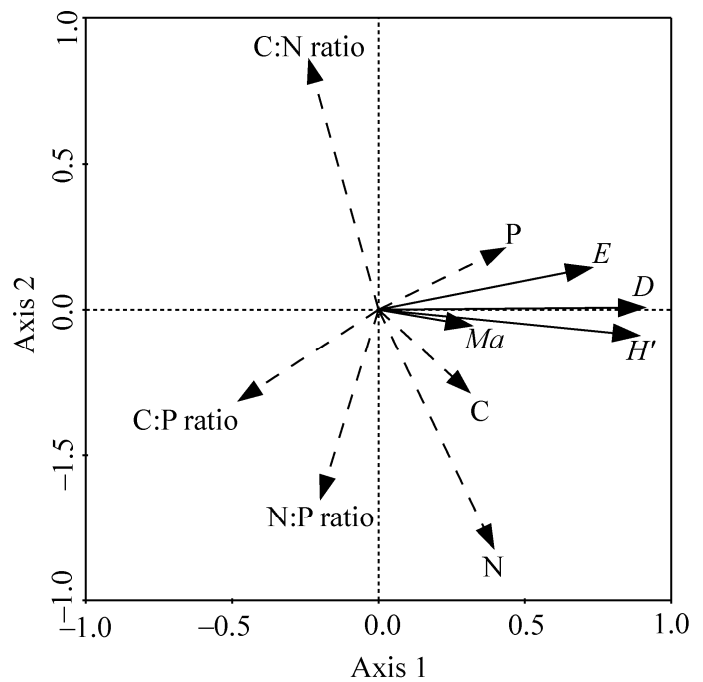

Fig. 4 Biplot diagram of redundancy analysis (RDA) for ecological stoichiometry and plant community diversity indices. In this biplot diagram, longer lines indicate stronger associations, and shorter lines indicate weaker associations. When the angle is between $0^{\circ}$ and $90^{\circ}$, there is a positive correlation between two variables; when the angle is between $90^{\circ}$ and $180^{\circ}$, there is a negative correlation between two variables; when the angle is $90^{\circ}$, no correlation is observed between two variables. C, carbon; $\mathrm{N}$, nitrogen; $\mathrm{P}$, phosphorus; $\mathrm{N}$, nitrogen; $D$, Simpson index; $H^{\prime}$, Shannon-Wiener index; $M a$, Margalef index; $E$, Pielou index. 
explained 2\%. Only axis 1 reflected the relationship between ecological stoichiometry and plant community diversity index. The results of RDA indicated that $\mathrm{C}: \mathrm{N}$ ratio and $\mathrm{N}$ concentration played important roles in explaining plant community diversity among all concentrations and ratios. The Simpson index was strongly and positively correlated with $\mathrm{P}$ concentration, and was weakly and positively correlation with $\mathrm{C}$ and $\mathrm{N}$ concentrations (Fig. 4). In contrast, C:N and N:P ratios had strong negative correlations with Simpson index, and $\mathrm{C}: \mathrm{P}$ ratio showed a weak negative correlation (Fig. 4). A clear positive correlation was found between the Shannon-Wiener index and $\mathrm{C}, \mathrm{N}$ and $\mathrm{P}$ concentrations (Fig. 4). Likewise, a negative correlation among these ratios was found, and the remaining indices showed similar patterns as well (Fig. 4).

The effects of concentrations and ratios on plant community diversity index were different, and it is not possible to conclude which concentration or ratio had the greatest impact on plant community diversity index. Therefore, A Monte-Carlo test was performed on $\mathrm{C}, \mathrm{N}$ and $\mathrm{P}$ concentrations and three ratios and obtained the sequence of importance of these stoichiometric variables. The importance sequence indicated that the most important element was $\mathrm{N}$ concentration (Table 3).

Table 3 Sequence of importance and Duncan's test of carbon (C), nitrogen (N) and phosphorous (P) concentrations and their ratios

\begin{tabular}{ccccc}
\hline Parameter & Sequence & Explanation & $F$ & $P$ \\
\hline N & 1 & 0.624 & 14.632 & 13.302 \\
C:N ratio & 2 & 0.571 & 12.583 & 0.002 \\
C:P ratio & 3 & 0.539 & 11.941 & 0.002 \\
P & 4 & 0.498 & 4.532 & 0.002 \\
C & 5 & 0.258 & 1.524 & 0.041 \\
N:P ratio & 6 & 0.103 & 0.235 \\
\hline
\end{tabular}

Figure 5 showed $t$-value results from RDA for the single stoichiometrical factor (i.e., $\mathrm{N}$ concentration, $\mathrm{P}$ concentration, $\mathrm{C}: \mathrm{N}$ and $\mathrm{C}: \mathrm{P})$ influencing plant community diversity indices. The Simpson index, the Pielou index and the Shannon-Wiener index all fell within the circle and the Margalef index partly fell into the circle with solid line (Fig. 5a). This implied that $\mathrm{N}$ concentration strongly and positively correlated with the Pielou index, the Simpson index and the Shannon-Wiener index, and weakly and positively correlated with the Margalef index. In other words, with an increase in $\mathrm{N}$ concentration, the values of plant community diversity indices increased as well. The C: $\mathrm{N}$ ratio revealed similar patterns to those of $\mathrm{N}$ concentration (Fig. $5 \mathrm{c}$ ). The Simpson index and the Shannon-Wiener index fell completely into the circle with solid line, and the Pielou index and the Margalef index partly fell into the circle with solid line (Fig. 5b). This result suggested that $\mathrm{P}$ concentration strongly and positively correlated with the Simpson index, the Pielou index and the Shannon-Wiener index, and weakly and positively correlated with the Pielou index and the Margalef index. And C:P ratio revealed similar patterns to those of C:N concentrations (Fig. 5d).

\section{Discussion}

\subsection{Characteristics of ecological stoichiometry}

This study demonstrates large differences in $\mathrm{C}, \mathrm{N}$ and $\mathrm{P}$ concentrations among different plant communities. $\mathrm{C}$ concentrations were highest at $\mathrm{T} 13$ community. This community has the largest number of Phragmites spp. that is a unique xerophilous plant (Tuboi and Hussain, 2018). Because T1 zone is the closest to the water source in the three sampled zones, a large number of Phragmites spp. grows in there. With the rapid growth of this species, the vascular bundles increase in the leaves and photosynthesis is enhanced, thereby leading to the effective accumulation of organic matter in the leaves (Behera et al., 2012). The highest $\mathrm{N}$ concentrations were observed in the species of Alhagi sparsifolia Shap. that dominates T23 community. A. sparsifolia is a naturally-growing and drought-tolerant plant that depends on groundwater (Xiang et al., 2018). If the plant is close to water source, its growth might be inhibited (Zhang et al., 

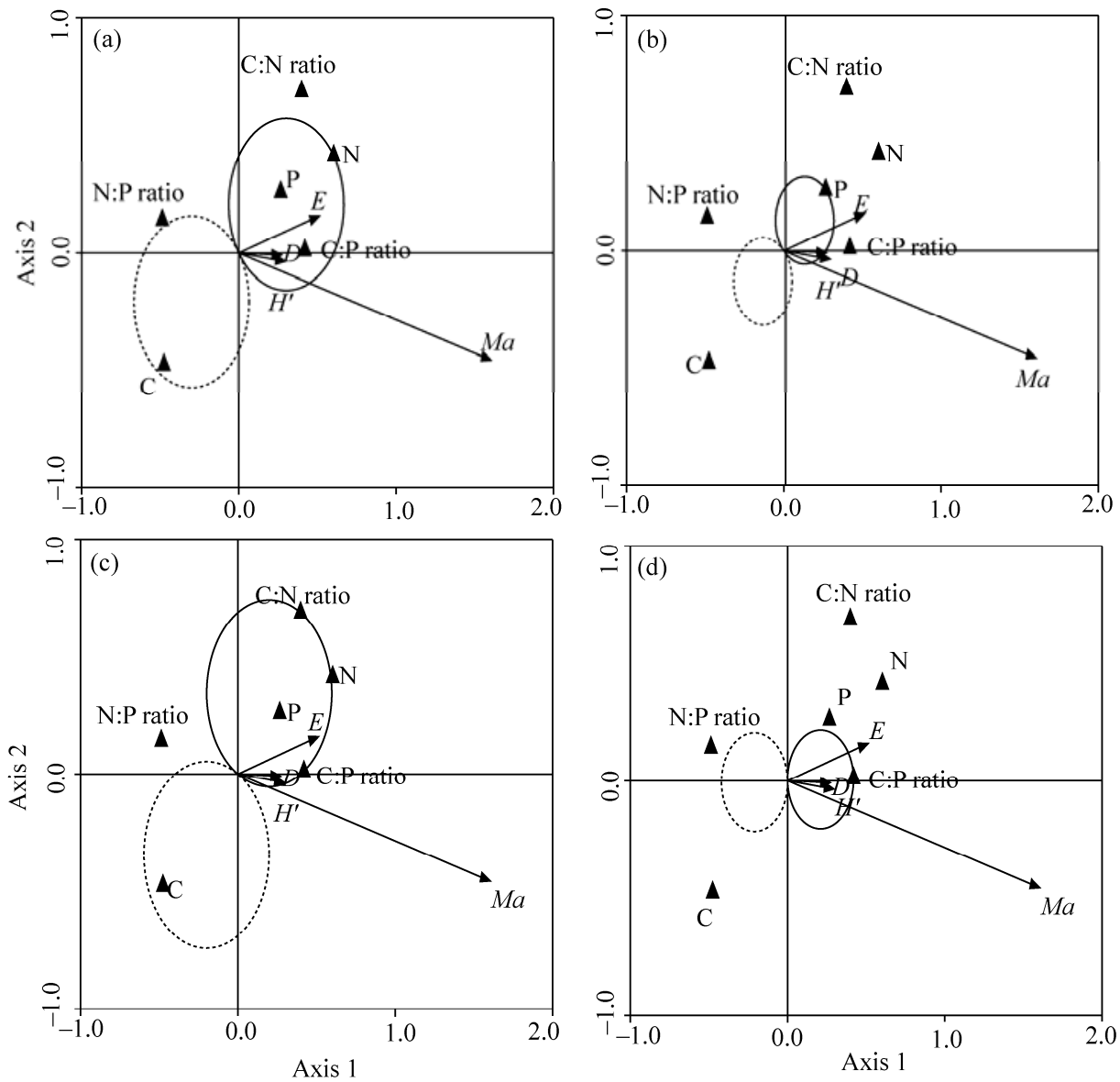

Fig. $5 t$-value results from RDA for single stoichiometrical factor influencing plant community diversity indices. (a), N concentration; (b), $\mathrm{P}$ concentration; (c), C:N ratio; (d), C:P ratio. The solid circle indicates positive correlation and the dotted circle indicates negative correlation. Plant community diversity indices fall into the solid circle, indicating a positive correlation with the elemental concentration or ratio. Plant community diversity indices fall into the dotted circle indicating a negative correlation with the elemental concentration or ratio. $\mathrm{C}$, carbon; N, nitrogen; P, phosphorus; N, nitrogen; $D$, Simpson index; $H$, Shannon-Wiener index; $M a$, Margalef index; $E$, Pielou index.

2018). On the contrary, if the plant is far away from water source, it is likely that less water cannot meet its growth need. As such, the moderate amount of water is most beneficial for the growth of the plant. Moreover, A. sparsifolia is a leguminous plant that has high $\mathrm{N}$ fixing ability and utilization efficiency (Lei et al., 2014). All in all, the characteristics of ecological stoichiometry reflect the vegetation component of the community and the nutrient absorption and utilization of the vegetation.

In general, $\mathrm{N}$ and $\mathrm{P}$ are assumed to be the two most limiting elements for plant growth (Elser et al., 2000; Elser et al., 2007; Qu et al., 2017). We found a significant difference in N:P ratios among different plant communities. The N:P ratio are higher than 16 in some communities, indicating that these communities were strongly P-limited (Yan et al., 2015; Yu et al., 2017b), and other communities that the N:P ratio are less than 14, were more limited by N (Plach et al., 2017). However, factors affecting plant N:P ratio are complex and comprehensive (Elser et al., 2007). The nutrient restriction in different communities are controlled by many factors, and the interaction between plant elements makes N:P ratio more complicated (Yan et al., 2015; Plach et al., 2017). Hence, the mechanism behind it needs further research.

\subsection{Characteristics of plant community diversity}

This study showed that the communities in T1 zone had the highest Simpson index values, 
indicating that they had strong anti-interference abilities. Because of the intermittent erosion by the Tarim River for a long time, the communities are more resistant to interference (Sures et al., 1999; Bu et al., 2017). However, other communities with poor anti-interference abilities have higher self-healing abilities after habitat destruction. The results indicate that dominant species can play a leading role in maintaining community structure and ecological function (Zhang et al., 2017). The values of the Shannon-Wiener index of the T11 and T16 communities in T1 zone were high, indicating that the structure and composition of these communities are more complicated. In contrast, the T31 community in T3 zone had a low value of the Shannon-Wiener index, pointing to a simpler community structure. The T11 and T16 communities in T1 zone are located closer to the Tarim River and are not subjected to drought stress. The water resources are relatively abundant and thus more plant species could survive in there (Merritt et al., 2010). In contrast, the T31 community in T3 zone is far from the river, and only a handful of desert species that overcome drought stress could survive in there. The values of Margalef index and Pielou index in the plant communities of $\mathrm{T} 1$ zone were higher than those of the other zones, reflecting the high richness of species and abundant distribution of species in $\mathrm{T} 1$ zone. This result may be attributed to the fact that the plant communities in $\mathrm{T} 1$ zone are closest to the water source and have plenty of water that supports more species to survive and grow in there (Merritt et al., 2010).

\subsection{Correlations between ecological stoichiometry and plant community diversity index}

The results supported our hypothesis that ecological stoichiometry and plant community diversity were related. It is possible that the ecological stoichiometry is important in driving plant community diversity. Previous studies have found that $\mathrm{C}$ is the main element for plant, and compared with other nutrient, its concentration is high and stable (Heyburn et al., 2017), but C is not a key element that limits plant growth (Makino et al., 2003; Heyburn et al., 2007). The result showed no significant correlation between plant community diversity and $\mathrm{C}$ concentration was found, further confirming this latter view. In our study, $\mathrm{N}$ and $\mathrm{P}$ concentrations were important to plant community diversity indices that showed a significant correlation with $\mathrm{N}$ and $\mathrm{P}$ concentrations. Study has showed that changes in $\mathrm{N}$ and $\mathrm{P}$ concentrations had an impact on plant community diversity (Zhao et al., 2010). Both the increase and decrease of $\mathrm{N}$ and $\mathrm{P}$ concentrations will affect the growth rate of plants, thus changing plant community diversity (Frenken et al., 2017). The sequence of importance of ecological stoichiometry on plant community diversity shows that $\mathrm{C}: \mathrm{N}$ and $\mathrm{C}: \mathrm{P}$ ratios also had significant impacts except for $\mathrm{N}$ concentration. The $\mathrm{C}: \mathrm{N}$ and $\mathrm{C}: \mathrm{P}$ ratios provide insight into plant's ability to absorb nutrients and assimilate $\mathrm{C}$ (Bell et al., 2018), to a certain extent, they can also reflect the nutritional efficiency of plant (Liu et al., 2010). Plant communities have different $C$ sequestration efficiencies, while $C$ accumulation efficiency and storage capacities are associated with $\mathrm{N}$ and $\mathrm{P}$ supplies that limit plant growth. Ultimately, ecological stoichiometry and plant community diversity appeared to be closely linked (Castellanos et al., 2018).

\section{Conclusions}

The importance of ecological stoichiometry in driving plant community diversity within a desert ecosystem was confirmed in this study. Firstly, the closer to the riparian, the greater the stoichiometric concentration of the community was, especially the $\mathrm{C}$ and $\mathrm{N}$ concentrations. Secondly, the closer to the riparian, the greater the plant community diversity index was. However, the plant community diversity index showed an opposite pattern when the distance to the riparian continues increase. What's more, RDA showed that $\mathrm{N}$ concentration was a key factor affecting plant community diversity in the Tarim River. In conclusion, under extreme environment of lacking nutrients and water, desert plants in Tarim River have formed special characteristics of ecological stoichiometry to maintain plant community diversity.

\section{Acknowledgements}

The study was funded by the National Natural Science Foundation of China (41461105). We thank Dr. Emily 
DRUMMOND (The University of British Columbia, Canada) for her assistance in English language and grammatical editing of the manuscript.

\section{References}

Allen A P, Gillooly J F. 2009. Towards an integration of ecological stoichiometry and the metabolic theory of ecology to better understand nutrient cycling. Ecology Letter, 12(5): 369-384.

Bao S N. 2000. Soil Agrochemical Analysis. Beijing: China Agricultural Press, 20-38. (in Chinese)

Behera S K, Mishra A K, Sahu N, et al. 2012. The study of microclimate in response to different plant community association in tropical moist deciduous forest from northern India. Biodiversity and Conservation, 21(5): 1159-1176.

Bell D W, Denham S, Smith E M, et al. 2018. Temporal variability in ecological stoichiometry and material exchange in a tidally dominated estuary (North Inlet, South Carolina) and the impact on community nutrient status. Estuaries and Coasts, 41(8): 2223-2239.

Bu C N, Wang Y, Ge C H, et al. 2017. Dissimilatory nitrate reduction to ammonium in the Yellow River Estuary: Rates, abundance, and community diversity. Scientific Reports, 7(1): 6830-6853.

Bustos-Segura C, Poelman E H, Reichelt M, et al. 2017. Intraspecific chemical diversity among neighbouring plants correlates positively with plant size and herbivore load but negatively with herbivore damage. Ecology Letters, 20(1): 87-97.

Cao Y, Chen Y M. 2017. Ecosystem C:N:P stoichiometry and carbon storage in plantations and a secondary forest on the Loess Plateau, China. Ecological Engineering, 105: 125-132.

Castellanos A E, Llano-Sotelo J M, Machado-Encinas L I, et al. 2018. Foliar C, N, and P stoichiometry characterize successful plant ecological strategies in the Sonoran Desert. Plant Ecology, 219(7): 775-788.

Chen Y. 2013. Habitat suitability modeling of amphibian species in southern and central China: environmental correlates and potential richness mapping. Science China Life Sciences, 56(5): 476-484.

Conti G, Díaz S. 2013. Plant functional diversity and carbon storage-an empirical test in semi-arid forest ecosystems. Journal of Ecology, 101(1): 18-28.

Elser J J, Fagan W F, Denno R F, et al. 2000. Nutritional constraints in terrestrial and freshwater food webs. Nature, 408(6812): 578-580.

Elser J J, Bracken M E S, Cleland E E, et al. 2007. Global analysis of nitrogen and phosphorus limitation of primary producers in freshwater, marine and terrestrial ecosystems. Ecology Letters, 10(12): 1135-1142.

Elser J J, Sterner R W, Gorokhova E, et al. 2010. Biological stoichiometry from genes to ecosystems. Ecology Letters, 3(6): 540-550.

Frenken T, Wierenga J, Gsell A S, et al. 2017. Changes in N:P supply ratios affect the ecological stoichiometry of a toxic cyanobacterium and its fungal parasite. Frontiers in Microbiology, 8(1015): 115-126.

Freudenberger L, Hobson P R, Schluck M, et al. 2012. A global map of the functionality of terrestrial ecosystems. Ecological Complexity, 12(1): 13-22.

Frost P C, Stelzer R S, Lamberti G A, et al. 2002. Ecological stoichiometry of trophic interactions in the benthos: Understanding the role of C:N:P ratios in lentic and lotic habitats. Journal of the North American Benthological Society, 21(4): 515-528.

Gong L, He G, Liu W G. 2016. Long-term cropping effects on agricultural sustainability in Alar Oasis of Xinjiang, China. Sustainability, 8(1): 61-78.

Grażyna P, Ostrowska A. 2018. Nutrient demand and elemental stoichiometry of plants in wetland ecosystems in the Biebrza Valley, Poland. Journal of Elementology, 23(3): 887-899.

Haddad N M, Crutsinger G M, Gross K, et al. 2011. Plant diversity and the stability of foodwebs. Ecology Letters, 14(1): $42-46$.

Halvorson H M, Sperfeld E, Evans-White M A. 2017. Quantity and quality limit detritivore growth: mechanisms revealed by ecological stoichiometry and co-limitation theory. Ecology, 98(12): 2995-3002.

Heyburn J, Mckenzie P, Crawley M J, et al. 2017. Effects of grassland management on plant C:N:P stoichiometry: implications for soil element cycling and storage. Ecosphere, 8(10): 156-177.

Hsu J C. 1996. Multiple Comparisons. New York: Springer, 56-66.

Huang J, Yu H, Liu J, et al. 2018. Phosphorus addition changes belowground biomass and C:N:P stoichiometry of two desert steppe plants under simulated N deposition. Scientific Reports, 8: 3400 .

Kerkhoff A J, Enquist B J, Elser J J, et al. 2005. Plant allometry, stoichiometry and the temperature-dependence of primary productivity. Global Ecology and Biogeography, 14(6): 585-598.

Li Y G, Zhou X B, Zhang Y M. 2019. Shrub modulates the stoichiometry of moss and soil in desert ecosystems, China. Journal 
of Arid Land, 11(4): 579-594.

Liu J, Liang S C, Liu F H, et al. 2005. Invasive alien plant species in China: regional distribution patterns. Diversity and Distributions, 11(4): 341-347.

Liu Z F, Fu B J, Zheng X X, et al. 2010. Plant biomass, soil water content and soil N:P ratio regulating soil microbial functional diversity in a temperate steppe: A regional scale study. Soil Biology and Biochemistry, 42(3): 445-450.

Liu Z Y, Baoyin T, Sun J, et al. 2018. Plant sizes mediate mowing-induced changes in nutrient stoichiometry and allocation of a perennial grass in semi-arid grassland. Ecology and Evolution, 8(6): 3109-3118.

Makino W, Cotner J B, Sterner R W, et al. 2003. Are bacteria more like plants or animals? Growth rate and resource dependence of bacterial C:N:P stoichiometry. Functional Ecology, 17(1): 121-130.

Merritt D M, Nilsson C, Jansson R. 2010. Consequences of propagule dispersal and river fragmentation for riparian plant community diversity and turnover. Ecological Monographs, 80(4): 609-626.

Moorthi S D, Schmitt J A, Ryabov A, et al. 2016. Unifying ecological stoichiometry and metabolic theory to predict production and trophic transfer in a marine planktonic food web. Philosophical Transactions of the Royal Society B Biological Sciences, 371(1694): 1-10.

Naeem S, Li S. 1997. Biodiversity enhances ecosystem reliability. Nature, 390(6659): 507-509.

Pelini S L, Diamond S E, Nichols L M, et al. 2014. Geographic differences in effects of experimental warming on ant species diversity and community composition. Ecosphere, 5(10): 1-12.

Plach J M, Macrae M L, Ali G A, et al. 2017. Supply and transport limitations on phosphorus losses from agricultural fields in the lower great lakes region, Canada. Journal of Environmental Quality, 47(1): 96-105.

Qu F Z, Meng L, Yu J B, et al. 2017. Influences of micro-geomorphology on the stoichiometry of C, N and P in chenier island soils and plants in the Yellow River Delta, China. PloS ONE, 12(12): e0189431.

Reich P B, Hobbie S E, Lee T, et al. 2006. Nitrogen limitation constrains sustainability of ecosystem response to $\mathrm{CO}_{2}$. Nature, 440(7086): 922-925.

Saitta A, Anslan S, Bahram M, et al. 2018. Tree species identity and diversity drive fungal richness and community composition along an elevational gradient in a Mediterranean ecosystem. Mycorrhiza, 28(1): 39-47.

Sardans J, Rivas-Ubach A, Peñuelas J. 2011. Factors affecting nutrient concentration and stoichiometry of forest trees in Catalonia (NE Spain). Forest Ecology and Management, 262(11): 2024-2034.

Seastedt T R, Vaccaro L. 2001. Plant species richness, productivity, and nitrogen and phosphorus limitations across a snowpack gradient in alpine tundra, Colorado, U.S.A. Arctic Antarctic \& Alpine Research, 33(1): 100-106.

Shang B, Feng Z, Li P, et al. 2018. Elevated ozone affects C, N and P ecological stoichiometry and nutrient resorption of two poplar clones. Environmental Pollution, 234: 136-144.

Snyder W E, Snyder G B, Finke D L, et al. 2006. Predator biodiversity strengthens herbivore suppression. Ecology Letters, 9(7): 789-796.

Soufbaf M, Fathipour Y, Hui C. 2017. Artificial diversity of plant-insect communities and modern crop stoichiometry in small closed patches in greenhouse. Journal of Agricultural Science and Technology, 19(6): 1291-1302.

Sperfeld E, Wagner N D, Halvorson H M, et al. 2017. Bridging ecological stoichiometry and nutritional geometry with homeostasis concepts and integrative models of organism nutrition. Functional Ecology, 31(2): 286-296.

Sures B, Knopf K, Würtz J, et al. 1999. Richness and diversity of parasite communities in European eels Anguilla anguilla of the River Rhine, Germany, with special reference to helminth parasites. Parasitology, 119(3): 323-330.

Tao Y, Wu G L, Zhang Y M, et al. 2016. Leaf N and P stoichiometry of 57 plant species in the Karamori Mountain Ungulate Nature Reserve, Xinjiang, China. Journal of Arid Land, 8(6): 935-947.

Tilman D, Wedin D, Knops J. 1996. Productivity and sustainability influenced by biodiversity in grassland ecosystems. Nature, 379(6567): 718-720.

Tuboi C, Hussain S A. 2018. Plant community structure of the floating meadows of a hypereutrophic wetland in the Indo-Burma biodiversity hotspot. Aquatic Botany, 150: 71-81.

Vilela D S, Ferreira R G, Del-Claro K. 2016. The Odonata community of a Brazilian vereda: seasonal patterns, species diversity and rarity in a palm swamp environment. Bioscience Journal, 32(2): 486-495.

Xiang Y L, Xiang Y X, Wang L P, et al. 2018. Effects of sewage sludge modified by coal gasification slag and electron beam irradiation on the growth of Alhagi sparsifolia Shap. and transfer of heavy metals. Environmental Science and Pollution Research, 25(12): 11636-11645.

Yachi S, Loreau M. 1999. Biodiversity and ecosystem productivity in a fluctuating environment: the insurance hypothesis. Proceedings of the National Academy of Sciences of the United States of America, 96(4): 1463-1471.

Yan E R, Wang X H. 2008. N:P stoichiometry in secondary succession in evergreen broad-leaved forest, Tiantong, East China. 
Journal of Plant Ecology, 32(1): 13-22. (in Chinese)

Yan W, Zhong Y, Zheng S, et al. 2016. Linking plant leaf nutrients/stoichiometry to water use efficiency on the Loess Plateau in China. Ecological Engineering, 87(12): 124-131.

Yan Z B, Kim N, Han X W, et al. 2015. Effects of nitrogen and phosphorus supply on growth rate, leaf stoichiometry, and nutrient resorption of Arabidopsis thaliana. Plant and Soil, 388(1-2): 147-155.

Yan Z, Han W X, Peñuelas J, et al. 2016. Phosphorus accumulates faster than nitrogen globally in freshwater ecosystems under anthropogenic impacts. Ecology Letters, 19(10): 1237-1246.

Yang Y, Liu B R, An S S. 2018. Ecological stoichiometry in leaves, roots, litters and soil among different plant communities in a desertified region of Northern China. Catena, 166: 328-338.

Yang Y H, Chen Y N, Li W L. 2009. Relationship between soil properties and plant diversity in a desert riparian forest in the lower reaches of the Tarim River, Xinjiang, China. Arid Land Research and Management, 23(4): 283-296.

Yang Y H, Luo Y. 2011. Carbon: nitrogen stoichiometry in forest ecosystems during stand development. Global Ecology and Biogeography, 20(2): 354-361.

Yu H, Fan J, Harris W, et al. 2017a. Relationships between below-ground biomass and foliar N:P stoichiometry along climatic and altitudinal gradients of the Chinese grassland transect. Plant Ecology, 218(6): 661-667.

Yu H, Fan J, Li Y. 2017b. Foliar carbon, nitrogen, and phosphorus stoichiometry in a grassland ecosystem along the Chinese grassland transect. Acta Ecologica Sinica, 37(3): 133-139. (in Chinese)

Zechmeister-Boltenstern S, Keiblinger K M, Mooshammer M, et al. 2015. The application of ecological stoichiometry to plant-microbial-soil organic matter transformations. Ecological Monographs, 85(2): 133-155.

Zeng Q, Lal R, Chen Y, et al. 2017. Soil, leaf and root ecological stoichiometry of Caragana korshinskii on the Loess Plateau of China in relation to plantation age. PloS ONE, 12(1): e0168890.

Zhang B, Gui D W, Gao X P, et al. 2018. Controlling soil factor in plant growth and salt tolerance of leguminous plant Alhagi sparsifolia Shap. in saline deserts, Northwest China. Contemporary Problems of Ecology, 11(1): 111-121.

Zhang C H, Willis C G, Klein J A, et al. 2017. Recovery of plant species diversity during long-term experimental warming of a species-rich alpine meadow community on the Qinghai-Tibet Plateau. Biological Conservation, 213: 218-224.

Zhang J, Zhao N, Liu C, et al. 2017. C:N:P stoichiometry in China's forests: From organs to ecosystems. Functional Ecology, 55(10): 33-68.

Zhang Q, Bell L W, Shen Y, et al. 2018. Indices of forage nutritional yield and water use efficiency amongst spring-sown annual forage crops in north-west China. European Journal of Agronomy, 93(5): 1-10.

Zhao Y J, Liu B, Zhang W G, et al. 2010. Effects of plant and influent C:N:P ratio on microbial diversity in pilot-scale constructed wetlands. Ecological Engineering, 36(4): 441-449. 